\title{
Discovery Character Experiment Worksheet on Temperature and Heat Material of Grade X Vocational School
}

\author{
Lieza Fadzilah*, Tantri Mayasari², Andista Candra Yusro ${ }^{3}$ iD \\ ${ }^{1,2,3}$ Department of Physics Education, University of PGRI Madiun, Jawa Timur, Indonesia \\ *Corresponding author: liezafadzilah@gmail.com
}

\begin{abstract}
Student Worksheet (LKS) is a learning media for experimental activities which as a source of student learning which can provide experiences for students, develop skills, and influence their attitudes. The purpose of this study is to produce a Worksheet Discovery-Character Experiment to hone the scientific attitudes and character of students that are suitable to be used in learning. This research is a 4D development study but only reached the development stage. Data collected in the form of LKS feasibility data from experts (lecturers and teachers). Based on the results of the analysis, it was concluded that the Discovery-Character Experiment worksheet (discovery learning integrated character education) is very feasible to use with an average percentage of $93 \%$. This worksheet is equipped with 3 Temperature and Heat experiment worksheets, concept maps, discussion material, practice questions, and self-evaluation related to students' scientific attitudes and characters. Based on the results of the study, it was concluded that the worksheet was arranged using discovery learning that is integrated in character education at the temperature and heat material of class X vocational high school. Each learning activity which integrated discovery learning can build students' character and scientific attitude.
\end{abstract}

Keywords: LKS; Discovery Learning; Character Building; Scientific Attitude; Student Character

$\begin{array}{lll}\text { History: } & \text { Publisher: Undiksha Press } \\ \text { Received } & : 9 \text { July } 2020 & \text { Licensed: This work is licensed under } \\ \text { Revised } & : 4 \text { Auguts } 2020 & \text { a Creative Commons Attribution 3.0 License } \\ \text { Accepted } & : \text { 20 September } 2020 & \end{array}$

\section{Introduction}

Physics cannot be separated from the existence of scientific activities in the form of experiments. A person can find concepts, new knowledge, and also can hone skills in experimenting and scientific attitudes through those experiments. Moreover, in the process of learning physics, the experiment is needed thus learning is not only transfer knowledge which ultimately makes students feel bored while learning (Marjito \& Rizki, 2019; Masfufah \& Mahardika, 2015). Learning science is difficult to do without conducting experiments, these experiments are based on scientific knowledge and understanding. Moreover, those experiments are good method to be used in learning (Ghavifekr \& Rosdy, 2015; Trumper, 2002). Experimental learning activities can motivate students to learn, improve students' skills in experimenting and using experimental tools, and hone their scientific attitudes. In addition, experimental activities can support students in understanding scientific concepts and principles. Experimental activities also can give positive impact on students' attitudes towards science (physics), scientific attitudes, scientific discoveries, concept development and skills process (Nasar \& Kaleka, 2019). 
Scientific attitude (scientific attitude) is as important as aspects of student knowledge. Scientific attitude is the most important outcome of learning science (Gokul \& Malliga, 2015; Singh \& Mishra, 2014). Scientific attitude can be identified through the attitude of curiosity, attitude of respect for data/facts, attitude of critical thinking, attitude of discovery and creativity, attitude of open mindedness, attitude of perseverance, attitude of working with others, attitude of desire to accept uncertainty, and attitude of an environmentally sensitive. This scientific attitude is directly related to scientific activities (experiments) conducted by students (Sujana \& Jayadinata, 2018; Zulirfan et al., 2017).

Scientific attitude is also closely related to student character. The characters are innate, heart, soul, personality, behavior, personality, and temperament. Character defined as a combination of aspect of cognitive, affective, and moral understanding behavior, dediction/obedience of moral and emotional, and moral conduct. In the school environment, character building is necessary and important thing to be done (Berkowitz \& Simmons, 2003; Supriyadi, 2015). Character education needs to be included in the school environment, because: (1) the young generation is morally weak thus, many of them are hurting each other, (2) it is important to instil character values in the young generation for the future, (3) school has an important role when the student environment does not support the cultivation and development of moral values (Machin, 2014).

Regarding the scientific attitude and character of students, through observation in one private Madiun Vocational School consisting of 28 male students, it was found that the scientific attitude of students were: 1-3 students who were active to ask questions (students who had a curious attitude) and the rest were listening; open thinking and cooperation were also lacking. 4 groups out of 6 groups of experimental activities, were looking for answers from other groups, or even in the groups there are those who did not do it, or only by one person; students' critical thinking attitude is also still lacking, only 35\% who dare to ask new things or correct the information conveyed by the teacher; attitude of discovery and creativity in both categories, students can vary material or use tools in experimental activities. While the students' character was found that: discipline attitude was still lacking; students also sometimes lie when permission to go to the bathroom but go to the canteen; student solidarity is also lacking, students are still picky about friends in groups. To control and overcome these problems models, methods and learning media that are appropriate to the characteristics of students are needed.

One learning model that can develop scientific attitudes is discovery learning. In discovery learning, students were asked to be able to find concepts or study material through the results of data or information obtained from observational or experimental activities and to develop students' scientific attitudes. Meanwhile, to support discovery learning in experimental activities, media is needed in the form of student worksheets (Asmarani \& Idrus, 2017).

Student Worksheets (LKS) are learning media that can help teachers in science learning activities and as a learning resource for students which can provide experience and skills in the learning process and have a positive effect on students' attitudes or characters. LKS can turn learning into a student center, make it more effective and make the material is well delivered (Ariaji \& Abubakar, 2017; Kaleka \& Ika, 2018). Through observing one of the Madiun City Private Vocational Schools, it was found that media is often used in the form of PowerPoint slides, videos and images related to the material, and books as learning resources which leading to the learning that lacks experience and skills as well as the attitude of students also cannot be sharpened. Moreover, the worksheets that were used consist of practice questions and also simple experimental activities. However, this worksheet has not trained students to find problems that must be solved and provided temporary answers related to these problems. The worksheet also has not been able to hone the scientific attitude and 
character of students in learning. On the other hand, LKS can also hone scientific attitudes, process skills, and increase students' interest in learning (Sintia et al., 2015).

Based on the aforementioned problems, it is necessary to develop worksheets in experimental learning that can enhance scientific attitudes and instil character values. Therefore, the researcher developed a student worksheet based on Discovery-Character Experiment specifically on the temperature and heat material. Discovery-Character Experiment (DCE) is a learning that was developed from the results of a library research study in the form of discovery learning integrated character education in experimental activities. These learning steps are generally the same, namely stimulations, problem statements, observation and data collection, data processing, verification, and generalization. The difference lies on the purpose of this learning which is more emphasis on the development of scientific attitudes and the cultivation of character values without ignoring aspects of knowledge.

Therefore, researchers conducted research which aims to develop and produce worksheets discovery-character experiment, describe the structure or content of worksheets discovery-character experiment, and describe the feasibility of discovery-character experiment.

\section{Materials and Methods}

This research is a Research and Development (R\&D) with 4D model which includes define, design, develop and disseminate stage (Thiagarajan et al., 1974). However, due to Covid 19 pandemic, this development research only came to expert judgment at the development stage. Initial research was conducted at one of the Private Vocational Schools in Madiun City TBSM class from September to November 2019, while the development of the LKS was carried out from April to June 2020.

The data needed for this study was the score of the Discovery-Character Experiment worksheet. The instruments used included instrument validation sheets. This DiscoveryCharacter Experiment-based worksheet is considered appropriate if it meets didactic requirements, construction requirements, and technical requirements. The feasibility data were analyzed by using descriptive percentages (Enggayanti, 2013). The formulas used were:

$$
P=\frac{f}{N} \times 100 \%
$$

in which $P=$ percentage score, $f=$ number of scores obtained, $N=$ maximum score. The eligibility level criteria for LKS are shown in Table 1.

Table 1. Eligibility Level Criteria LKS

\begin{tabular}{ll}
\hline Interval & Criteria \\
\hline $21 \%<\mathrm{P} \leq 40 \%$ & Inadequate \\
$41 \% \leq \mathrm{P} \leq 60 \%$ & Decent enough \\
$61 \% \leq \mathrm{P} \leq 80 \%$ & Worthy \\
$81 \% \leq \mathrm{P} \leq 100 \%$ & Very decent \\
\hline
\end{tabular}

(Enggayanti, 2013) 


\section{Results and Discussion}

\section{The LKS structure based on Discovery-Character Experiment}

The LKS structure based on the Discovery-Character Experiment begins with the cover and the title of the LKS which is the Discovery-Character Experiment-Based Student Learning Worksheet shown in Figure 2. The cover picture was taken from the internet and the source was written on the cover. On the second page of the worksheet, there is an introduction and a table of contents (Figure 2) on one page, so that the worksheet is not too thick but can cover the whole content.

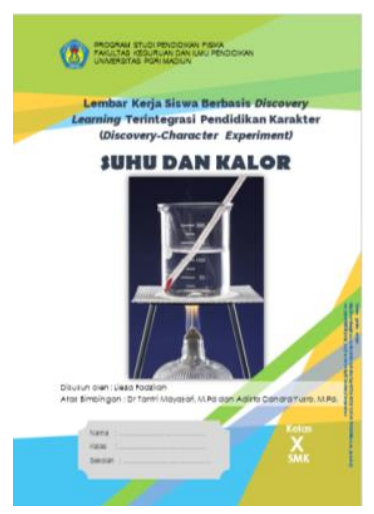

Figure 1. The LKS cover is based on Discovery-Character Experiment

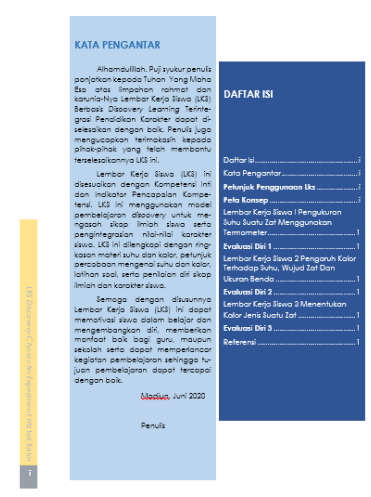

Figure 2. Preface and table of contents

On the next page, there are instructions for using the worksheet that contains Basic Competence (KD) and performance indicators for each worksheet shown in Figure 4. There is a concept map of temperature and heat material shown in Figure 5. The material for temperature and heat was designed for three meetings. Since researchers use experimentalbased learning, the researcher has designed the material in order to make the experiments can be conducted in each learning process even with simple experiment. Moreover, the Discovery-Character Experiment LKS on the temperature and heat material contains three sub-LKS namely LKS 1 Temperature Measurement of a Substance Using a Thermometer (figure 6), LKS 2 The Effect of Heat on Temperature, Substance, and Size of Objects (figure 7), and LKS 3 Determine the Specific Heat of a Substance. In each envelope sub LKS, there are indicators of achievement, learning objectives, and list of group names.

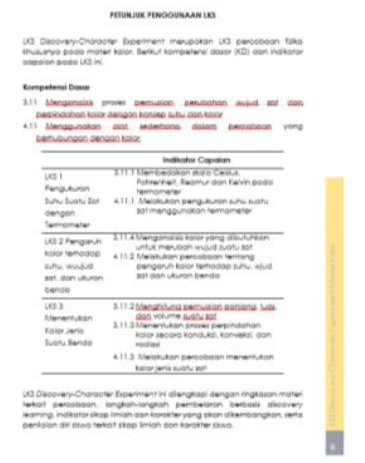

Figure 3. Instructions for using the LKS

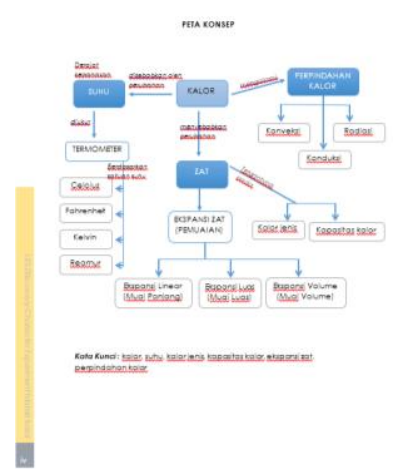

Figure 4. Map of Temperature and Heat Concepts in LKS 


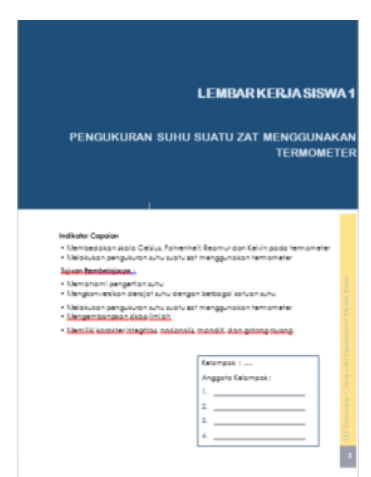

Figure 5. LKS 1 Temperature Measurement of a substance using a thermometer
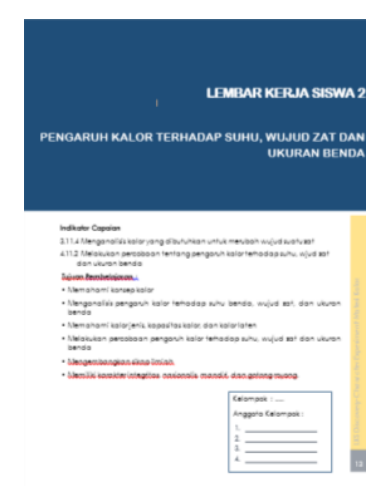

Figure 6. LKS 2 The Effect of Heat on Temperature, Substance, and Size of Objects

The worksheet was equipped with steps of discovery learning as shown in Figure 8. In each step of discovery learning there is always an indicator of scientific attitude and character that will be honed in the learning activities and can be shown in figure 8 . The discussion of the material which discussed together between students and teachers is not always conducted at the same time but adjusted to the conditions of learning. Sometimes, some of them were conducted at the beginning before the experiment, some of them were conducted after the experiment. While the materials were divided into three sections which were adjusted to the sub-worksheet. In the discovery step which was observation and data collection, in LKS there are simple experimental steps related to temperature and heat and have been equipped with the title of the experiment, the purpose of the experiment, tools and experimental material, the experimental results in the form of a table as shown in Figure 10. The discovery step, data processing, proof, and conclusions are made on the next page.

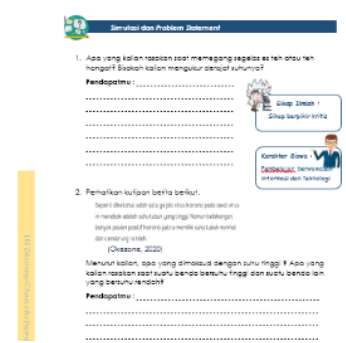

Figure 7. One of the syntax of discovery learning with a description of scientific attitudes and characters.

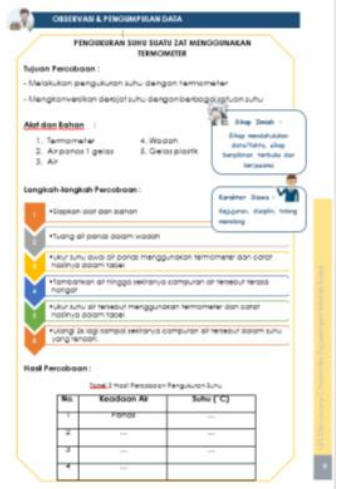

Figure 9. Trial activity sheet

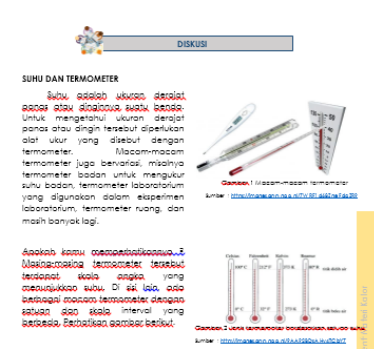

Figure 8. Summary of Material for Teacher and Student Discussion

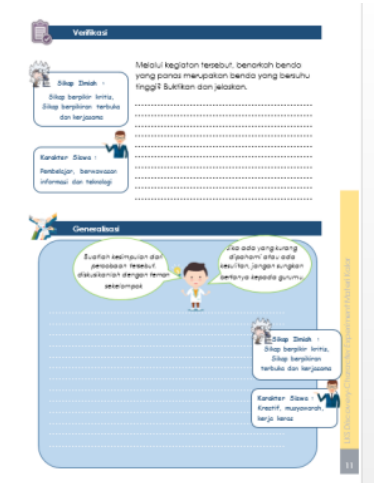

Figure 1 The page on the LKS's Proof of Discovery and Simuality Steps 
This student worksheet was equipped with a self-evaluation which is an assessment of students' self-related scientific attitudes and character of students that were adjusted to the indicators of scientific attitudes and characters developed in learning (figure 12). Exercise questions related to temperature and heat were also provided thus, students can practice and evaluate the material they have learned (figure 13).

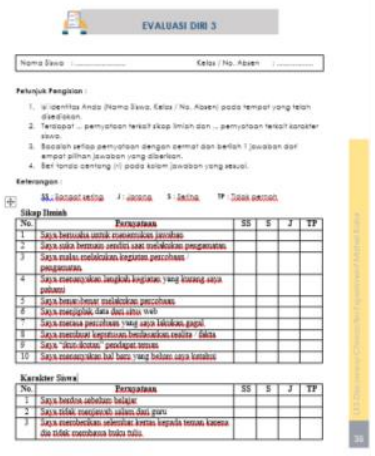

Figure 2 Self-Evaluation of Scientific Attitudes and Character of Students

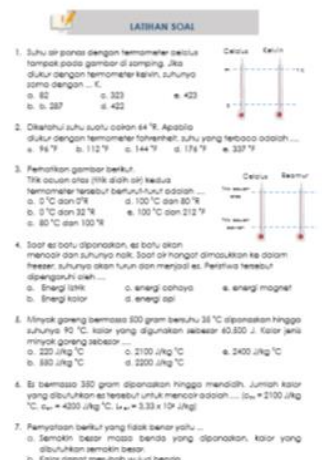

Figure 3 Exercise page for Temperature and Heat

Eligibility of LKS based on Discovery-Character Experiment

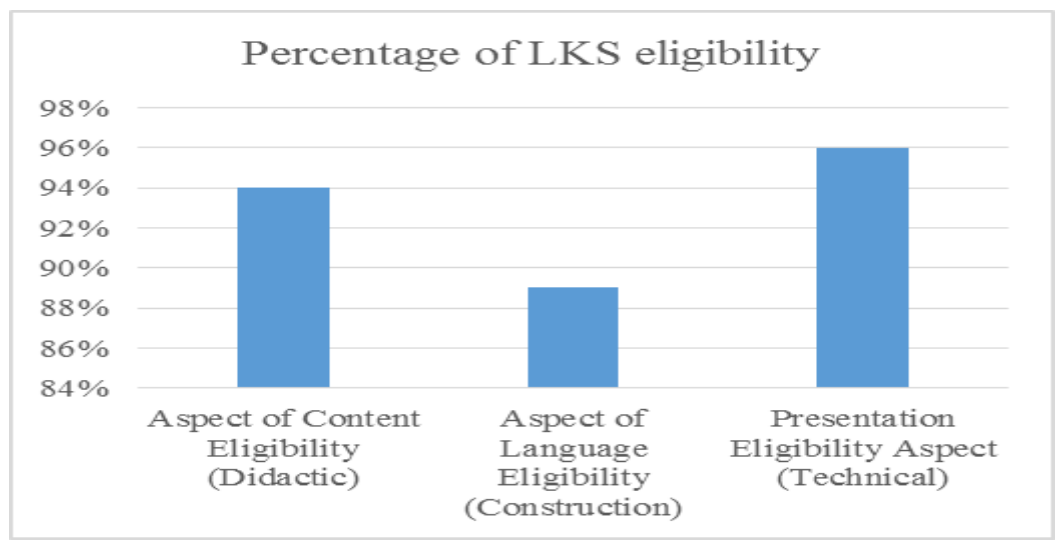

Figure 13. Feasibility Percentage of LKS based on Discovery-Character Experiment

The LKS eligibility test was conducted by 3 validators, namely two lecturers and one teacher which can be seen in Figure 13. Based on the results of the analysis, it was found that the average percentage of worksheet based on Discovery-Character Experiment was 93\% which indicated that the worksheet was very feasible to use. The content eligibility questionnaire consists of the compatibility of the material with $\mathrm{KI}$ and $\mathrm{KD}$, the application of discovery learning, the integration of character values, and the integration of scientific attitudes. The aspect of language eligibility consists of the suitability of the language with the level of student ability, the suitability of the LKS writing rules, and the suitability of the use of foreign languages, while the feasibility aspect of the presentation consists of presentation techniques and supporting the presentation of material

This worksheet was developed for being used in temperature and heat experimental learning with discovery learning models that integrated character education. The aim is to develop student character through scientific attitudes in learning physics. explains, if students often carry out scientific activities, the attitude value of these scientific activities will affect the development of character (Machin, 2014). Previous research has also been carried out by 
(Enggayanti, 2013; Mayasari et al., 2015; Ristiyani, 2014). A research on the development of inquiry-based worksheets that integrated character education for grade VII with instilled character values, namely discipline, honesty, and curiosity and the results of the study found that the character has developed using these worksheets (Enggayanti, 2013). The development research in the form of worksheets with integrated scientific learning of character education for high school students on statistical fluid material with character values of curiosity, caution, responsibility, honest, critical, and environmental care (Mayasari et al., 2015). Whereas, a research on developing physics worksheets on light reflection \& refraction material with integrated scientific learning of character education. The characters that are instilled through LKS are honest, discipline, curiosity, and communicative (Ristiyani, 2014). Through work instructions, experimental activities, and LKS learning activities, the characters are raised so that the characters can be developed and implemented in daily life.

In general, this research is almost the same as the three studies integrating character education in learning. The difference is that the Discovery-Character Experiment LKS fosters student character through scientific attitudes, and the scientific attitude is obtained or honed from experimental activities with discovery learning models. The scientific attitude implemented in the worksheet is curiosity, critical thinking, respect for data/facts, openminded attitude and cooperation, discovery and creativity, and perseverance. The characters that are embedded are nationalist (disciplined, law-abiding), integrity (honesty, anticorruption, respect for human dignity), independent (courage, learner, creative, information and technology-oriented, fighting spirit, challenging, hard work), and mutual cooperation deliberation, volunteerism, anti-discrimination, solidarity, please help).

The stages of discovery learning in this worksheet are stimulation and statement of problems, observation and data collection, data processing, verification, and conclusions. Each stage is instilled by scientific attitudes and student character values, as shown in table 2 . These character values and scientific attitude can be honed through learning activities in LKS. In line with the opinion of Sartiyah \& Yulianti (2015) which was students can get used to behavior of scientists by using LKS in learning activities. As in the stimulation stage, students are given questions to be answered with their own sentences or opinions. At this stage, scientific attitudes such as curiosity and critical thinking are sharpened (Patrianingsih \& Kaseng, 2016). By answering stimulation questions in their own sentences, they can form independent characters such as courage, creative learner, information and technology oriented. During the observation and data collection stage, experimental activities related to temperature and heat are presented and experimental tools \& materials are provided as well as experimental steps. Experimental activities are adjusted in order to hone an attitude of discovery \& creativity and an attitude of open-minded \& cooperative. Through these activities, students' character values such as integrity (honesty, nationalism (law, discipline), independence (creative, learner, fighting power), mutual cooperation (deliberation, help, solidarity) can be developed.

At the data processing stage, data obtained by students from experimental activities is processed into graphs, or to find other data. Attitudes of prioritize facts / data, open-minded and cooperation, as well as the attitude of perseverance are sharpened in this activity. Character values such as integrity, nationalism, independence, mutual cooperation is also instilled in this learning activity. At the proof stage, students are asked to provide an opinion or analysis of the observation results and data collection and next, proving whether the previous opinion at the stimulation stage is the same as the results of the observation. The scientific attitude that is sharpened are critical thinking attitude, open minded attitude and cooperation attitude, and attitude always puts data/facts first. By honing the scientific attitude, it can affect the students' character such as independence, integrity, mutual cooperation, and nationalism. Scientific attitudes and character values are also honed in the 
conclusion stage with learning activities in which students make conclusions from the experiments or learning activities that have been carried out. According to research conducted by Patrianingsih \& Kaseng (2016), it was explained that the discovery learning model contributed well in shaping students' scientific attitudes, this was due to the use of learning models which was one of the drivers for the formation of students' scientific attitudes. On the other hand, Berkowitz \& Simmons (2003) explained that character education can be integrated with science education (including physics) with an expanded discussion of science in a social perpective, "participating in information reflection related to ethics in science", and participating in social activities related to scientific problems.

In every stage of discovery learning, there are two to four dimensions of scientific attitudes and character values that are honed. Therefore, in this worksheet the dimensions of scientific attitude and character values were divided into three learning activities for temperature and heat. Thus, the dimensions and characters to be embedded are adapted to the learning activities, learning materials, characteristics and abilities of students. Learning activities that were used in the form of experimental activities interspersed with data processing in the form of making graphics or finding other data and interspersed with discussion material so that learning remains active, knowledge can be conveyed well, and learning objectives can be achieved. Based on the feasibility test, it was found that the average feasibility of the Discovery-Character Experiment was 93\%. In accordance with the eligibility criteria for the worksheets from (Enggayanti, 2013), it was found that the worksheets were very feasibility to use.

\section{Conclusion}

Based on the results of the study, it was concluded that the worksheet was arranged using discovery learning that is integrated in character education at the temperature and heat material of $\mathrm{X}$ grade of vocational high school. In each learning activity which integrated discovery learning, students' characters and scientific attitudes can be built. The characters built are independent, integrity, nationalist and mutual cooperation, while the scientific attitude that is honed are the attitude of curiosity, the attitude of always stating facts, the attitude of thinking critically, the attitude of discovery and creativity, the attitude of openmindedness and cooperation, and the attitude of perseverance. This worksheet consists of 3 Temperature and Heat experiment worksheets, supplemented with concept maps, discussion material, practice questions, and self-evaluation related to students' scientific attitudes and characters. The level of eligibility of the criteria is very feasible thus, it can be used in learning.

\section{References}

Ariaji, R., \& Abubakar, A. (2017). Pengembangan Lembar Kerja Siswa (LKS) Kimia di SMA/MA Kelas X Terinternalisasi Nilai-Nilai Karakter Siswa. Eksakta: Jurnal Penelitian Dan Pengembangan MIPA, 32, 101-108.

Asmarani, A., \& Idrus, I. (2017). Peningkatkan Sikap Ilmiah Siswa Melalui Penerapan Model Discovery Learning. Jurnal Pendidikan Dan Pembelajaran Biologi, 1(1), 16-22.

Berkowitz, M. W., \& Simmons, P. E. (2003). Integrating Science Education and Character Education. The Role of Moral Reasoning on Socioscientific Issues and Discourse in Science Education, 19, 117-138. https://doi.org/10.1007/1-4020-4996-х_ 7

Enggayanti, D. L. (2013). Pengembangan LKS Berbasis Inkuiri Terintegrasi Pendidikan Karakter pada Materi Kalor untuk Siswa Kelas VII SMP RSBI. Universitas Negeri Semarang. 
Ghavifekr, S., \& Rosdy, W. A. W. (2015). Teaching and learning with technology: Effectiveness of ICT integration in schools. International Journal of Research in Education and Science, 1(2), 175-191.

Gokul, R., \& Malliga, T. (2015). A Study on Scientific Attitude among Pre Service Teachers. Research Journal of Recent Sciences, 4, 196-198.

Kaleka, M., \& Ika, Y. E. (2018). Developing the Character-Based Students Worksheet of Science with Inquiry Model for Students of Grade IX. Journal of Science Education Research, 2(2), 66-70.

Machin, A. (2014). Implementasi Pendekatan Saintifik, Penanaman Karakter dan Konservasi pada Pembelajaran Materi Pertumbuhan. Jurnal Pendidikan IPA, 3(1), 28-35.

Marjito, E. R., \& Rizki, K. (2019). Pengaruh Penerapan Model Pembelajaran Inside Outside Terhadap Hasil Belajar Siswa Kelas X SMAN 1 Sungai Raya Kabupaten Kubu Raya. Psikologi Perkembangan, October 2013, 1-224. https://doi.org/10.1017/CBO9781107415324.004

Masfufah, A. S., \& Mahardika, A. I. (2015). Hubungan Keaktifan Penggunaan Media Sosial terhadap Hasil Belajar Fisika Siswa Kelas X dan XI IPA di SMA Negeri Banjarmasin. Berkala Ilmiah Pendidikan Fisika, 3(3), 230-241.

Mayasari, H., Syamsurizal, \& Maison. (2015). Pengembangan Lembar Kerja Siswa (LKS) Berbasis Karakter melalui Pendekatan Saintifik pada Materi Fluida Statik untuk Sekolah Menengah Atas. EduSains, 4, 30-36.

Nasar, A., \& Kaleka, M. B. U. (2019). Effectiveness of Experimental Laboratory Methods on Understanding the Concept of Light, Science Processes Skills, And Scientific Attitudes of Students. Jurnal Pendidikan Fisika Universitas Muhammadiyah Makassar, 7(3), 262-270.

Patrianingsih, E. A., \& Kaseng, E. S. (2016). Model Pembelajaran Discovery Learning, Pemahaman Konsep Biologi, dan Sikap Ilmiah Peserta Didik. Jurnal Penelitian Pendidikan Insani, 19(2), 74-86.

Ristiyani, D. (2014). Pengembangan LKS Fisika Materi Pemantulan dan Pembiasan Cahaya Terintegrasi Karakter dengan Pendekatan Saintifik. Universitas Negeri Semarang.

Sartiyah, S., \& Yulianti, D. (2015). Pengembangan LKS Fisika Materi Kalor dan Perubahan Wujud Bermuatan Karakter dengan Pendekatan Scientific. Unnes Physics Education Journal, 4(1), 54-61.

Singh, U., \& Mishra, P. (2014). Study of Scientific Attitude Of B.Ed. And B.Ed. (Special) Pupil Teachers. Scholarly Research Journal for Interdisciplinary Studies, II, 1815-1822.

Sintia, R., Abdurrahman, \& Wahyudi, I. (2015). Pengembangan LKS Model Discovery Learning Melalui Pendekatan Saintifik Materi Suhu dan Kalor. Jurnal Pembelajaran Fisika, 3, 125-134.

Sujana, A., \& Jayadinata, A. K. (2018). Pembelajaran Sains di Sekolah Dasar (A. A. Syahid (ed.); 1st ed.). UPI Sumedang Press.

Supriyadi, E. (2015). Pendidikan dan Penilaian Karakter di Sekolah Menengah Kejuruan. Jurnal Cakrawala Pendidikan, 2. https://doi.org/10.21831/cp.v0i2.7590

Thiagarajan, S., Semmel, D. S., \& Semmel, M. I. (1974). Instructional Development for Training Teachers of Exceptional Children: A Sourcebook. Center for Innovation in Teaching the Handicapped. 
Trumper, R. (2002). What Do We Expect From Students' Physics Laboratory Experiments? Journal of Science Education and Technology, 11(3), 221-228. https://doi.org/10.1023/A:1016016417872

Zulirfan, Iksan, Z. H., Osman, K., M, S. N., \& Moh, S. (2017). Take-Home-Experiment: Enhancing Students' Scientific Attitude. Journal of Baltic Science Education, 828-837. 